\title{
PELAKSANAAN PEMBELAJARAN MENULIS CERITA FANTASI: STUDI KASUS DI KELAS VII SMP NEGERI 4 SURAKARTA
}

\author{
Dimas Putra Dwipa, Nugraheni Eko Wardhani, Atikah Anindyarini \\ Universitas Sebelas Maret \\ Email: dimas197.dp@student.ac.id
}

\begin{abstract}
Abstrak: Tujuan penelitian ini adalah: 1) Mendeskripsikan dan menjelaskan perencanaan pembelajaran menulis cerita fantasi pada siswa kelas VII H SMP N 4 Surakarta. 2) Mendeskripsikan dan menjelaskan pelaksanaan pembelajaran menulis cerita fantasi siswa kelas VII H SMP N 4 Surakarta. 3) Mendeskripsikan dan menjelaskan kendala pembelajaran menulis cerita fantasi siswa kelas VII H SMP N 4 Surakarta. 4) Mendeskripsikan dan menjelaskan upaya untuk mengatasi kendala pembelajaran menulis cerita fantasi siswa kelas VII H SMP N 4 Surakarta. Penelitian ini merupakan studi kasus dengan metode penelitian kualitatif. Dalam penelitian ini sumber data diperoleh dari informan yang merupakan guru bahasa Indonesia dan siswa kelas VII H di SMP Negeri 4 Surakarta. Sedangkan data yang diperoleh yaitu berupa dokumen yang relevan dengan fokus penelitian, yaitu hasil wawancara, silabus, dan RPP yang dimiliki oleh guru. Subjek dalam penelitian ini yaitu guru mata pelajaran Bahasa Indonesia kelas VII H dan siswa kelas VII H di SMP Negeri 4 Surakarta. Teknik penelitian yang digunakan dalam pemilihan subjek ini yaitu dengan menggunakan teknik purposive sampling. Teknik yang digunakan dalam pengumpulan data dalam penelitian ini ialah observasi, wawancara, dan analisis dokumen. Dalam penelitian ini dilakukan teknik triangulasi. Triangulasi yang dipilih dapat berupa triangulasi data dan metode. Dalam penelitian ini, data dianalisis dengan cara reduksi data, penyajian data, menarik kesimpulan.
\end{abstract}

Kata Kunci: implementasi, pembelajaran menulis, cerita fantasi, siswa

\section{IMPLEMENTATION OF LEARNING FANTASI STORIES: CASE STUDY IN CLASS VII OF SMP NEGERI 4 SURAKARTA}

\begin{abstract}
The aims of this research are: 1) Describe and explain learning planning to write fantasy story to students of class VII H SMP N 4 Surakarta. 2) Describe and explain the implementation of learning to write fantasy stories of class VII H students of SMP N 4 Surakarta. 3) Describe and explain the obstacles to learning to write fantasy stories of class VII H students of SMP N 4 Surakarta. 4) Describe and explain the efforts to overcome the obstacles to learning to write fantasy stories of class VII H students of SMP N 4 Surakarta. This research is a case study with qualitative research methods. In this study, data sources were obtained from informants who were Indonesian language teacher and students in VII H of SMP N 4 Surakarta. While the data obtained is in the form of documents that are relevant to the focus of the research, namely the results of interviews, syllabus, and lesson plans that are owned by the teacher. The subjects in this study were VII H Indonesian Language subject teacher and VII H's students at SMPN 4 Surakarta. The research technique used in selecting this subject is by using a purposive sampling technique. The technique used in collecting data in this study is observation, interviews, and document analysis. In this study triangulation techniques were carried out. The selected triangulation can be in the form of data triangulation and methods. In this study, data was analyzed by means of data reduction, data display, conclusions drawing.
\end{abstract}

Keywords: implementation, writing learning, fantasy stories, students

PENDAHULUAN

Kegiatan penelitian merupakan suatu cara untuk mendapatkan pengetahuan ataupun memecahkan permasalahan, yang dilakukan secara ilmiah, sistematis dan logis, serta 
menempuh langkah-langkah tertentu. Penelitian di bidang apa pun pada umumnya mempunyai kesamaan yang terletak pada langkah-langkah yang akan dilakukan. Meskipun dalam beberapa hal sering ditemui pelaksanaan yang dimodifikasi oleh peneliti yang bersangkutan sesuai dengan situasi ataupun kondisi yang sedang dihadapi.

Adapun secara garis besar langkahlangkah penelitian dapat dipilih menjadi beberapa fase, antara lain fase perencanaan, pelaksanaan, dan penulisan laporan. Adapun studi kasus termasuk ke dalam fase perencanaan penelitian yang diawali dengan memilih masalah secara garis operasional dan membuat batasanbatasan. Setelah menentukan masalah yang telah dipilih, baru dilakukan studi kasus.

Menulis merupakan sebuah proses kreatif menuangkan gagasan dalam bentuk tulis dengan tujuan memberitahu, meyakinkan, dan menghibur. Menurut Tarigan (2013:3) "Menulis merupakan keterampilan berbahasa yang digunakan untuk berkomunikasi secara tidak langsung atau tidak bertatap muka".

Tidak dapat dipungkiri bahwa saat ini tidak semua anak mempunyai hobi gemar membaca maupun menulis. Akan tetapi, terkadang sesuatu hal yang telah direncanakan bisa saja tidak sesuai dengan yang diharapkan. Ada yang berpendapat bahwa pemahaman antara guru dan murid mengenai cerita fantasi masih terbatas. Baik guru ataupun anak didik perpendapat bahwa menulis teks cerita fantasi itu sama dengan menulis teks cerita fabel dan legenda. Hal ini tentu saja kurang tepat karena menulis teks cerita fantasi tidak sebatas menulis teks legenda ataupun fabel saja. Ciri utama cerita fantasi dapat dilihat dari tokoh-tokoh dan tempatnya yang merupakan hasil fantasi yang tidak ada di kehidupan nyata (Kurniawan, 2014: 39).

Berdasarkan revisi Kurikulum 2013 cerita fantasi merupakan salah satu bentuk narasi di dalam pelajaran bahasa Indonesia kelas VII semester 1. Demikian itu tertera pada Kompetensi Inti (KI) 4 yaitu mencoba, mengolah, menyaji dalam ranah konkret (menggunakan, mengurai, merangkai, memodifikasi, dan membuat) dan ranah abstrak (menulis, membaca, menghitung, menggambar, dan mengarang) dengan Kompetensi Dasar (KD) 4.4 yaitu menyajikan gagasan kreatif dalam bentuk cerita fantasi secara lisan maupun tulis dengan memperhatikan struktur dan penggunaan bahasa

Menulis cerita fantasi berarti berbagi cerita kepada orang lain melalui sebuah tulisan. Menulis cerita fantasi mempunyai banyak manfaat, terutama bagi siswa. Dalam menulis cerita fantasi, siswa dapat melatih rasa percaya dirinya melalui katakata tanpa harus ada lawan bicara dalam menyampaikan sesuatu. Menulis juga dapat menjadi media belajar dalam menyampaikan sebuah ide ataupun gagasan. Selain itu, menulis cerita fantasi juga dapat membuat siswa menjadi lebih mudah dalam menemukan ide-ide baru dan gagasan mereka. Dalam pendidikan dibutuhkan suatu program untuk membelajarkan siswa, yang biasa disebut kurikulum. Dengan program itu para siswa melakukan berbagai kegiatan belajar, sehingga terjadi perubahan dan perkembangan tingkah laku siswa sesuai dengan tujuan pendidikan dan pembelajaran.

Akan tetapi, tidak dapat dipungkiri bahwa sesuatu yang telah direncanakan terkadang tidak sesuai harapan. Kebanyakan siswa kurang dapat menguasai dan mahir dalam pengungkapan bahasa secara efektif. Menuangkan gagasan dan pendapat bukanlah suatu pekerjaan yang mudah. Hal itu dikarenakan menulis membutuhkan sejumlah pengetahuan dan keterampilan. Faktor lain dari keterbatasan siswa dalam hal menulis adalah guru kurang tepat dalam memilih bahan ajar, metode, dan media pembelajaran, sehingga mengakibatkan siswa merasa kurang tertarik dan kurang minat dalam hal menulis. 
Melihat fenomena di atas, pembelajaran menulis di sekolah sangat diperlukan. Salah satu keterampilan tersebut adalah keterampilan menulis cerita fantasi. Dalam hal ini penulis tertarik untuk meneliti bagaimana proses pembelajaran menulis cerita fantasi di SMP Negeri 4 Surakarta.

\section{METODE PENELITIAN}

Penelitian yang dilakukan penulis menggunakan penelitian kualitatif dengan pendekatan studi kasus. Penelitian kualitatif mendeskripsikan dalam bentuk kata-kata dan bahasa mengenai apa yang dialalami oleh subjek peneliti seperti perilaku, tindakan, dan persepsi (Moleong, 2010). Metode deskriptif kualitatif digunakan untuk menggambarkan secara sistematik fakta atau bidang yang ditemukan selama berlangsungnya proses penelitian. Cara penelitian terhadap masalah empiris dengan prosedur yang telah ditetapkan sebelumnya dapat dilakukan dengan menggunakan metode studi kasus. Penelitian ini dapat dikatakan penelitian studi kasus karena penelitian ini lebih mementingkan proses dari pada hasil. Penelitian ini dilaksanakan di SMP Negeri 4 Surakarta yang beralamat di Jalan DI. Panjahitan 14, Setabelan, Kec. Banjarsari, Surakarta. SMP Negeri 4 Surakarta

Data dalam penelitian kualitatif berupa kata-kata yang bersumber dari pengamatan yang dilakukan secara langsung maupun hasil dokumentasi berupa wawancara yang didapat. Sumber data dalam penelitian ini menggunakan dokumen dan informan. Pemaparan sumber data sebagai berikut. Dalam penelitian ini menggunakan data yang berupa dokumen yang relevan dengan fokus penelitian, yaitu hasil wawancara, silabus, dan RPP yang dimiliki oleh guru. Informan pada penelitian ini adalah guru bahasa Indonesia dan beberapa siswa kelas VII H di SMP Negeri 4 Surakarta.

Teknik penelitian yang digunakan dalam pemilihan subjek ini yaitu dengan menggunakan teknik purposive sampling yaitu teknik pengambilan data dengan pertimbangan tertentu. Dalam penelitian ini subjek yang dipilih dianggap mengetahui permasalahan mendalam dan dapat memberikan informasi yang dibutuhkan oleh peneliti.

Data yang dihasilkan dalam penelitian kualitatif bersifat valid, reliabel, dan objektif. Penelitian data dapat dikatakan valid apabila tidak ada perbedaan antara yang dilaporkan peneliti dengan keadaan yang sesungguhnya. Dalam penelitian ini dilakukan teknik triangulasi. Triangulasi yang dipilih dapat berupa triangulasi data dan metode.

\section{HASIL DAN PEMBAHASAN}

Wawancara dilaksanakan dengan menggunakan teknik wawancara tidak terstruktur kepada narasumber. Narasumber pada penelitian ini adalah guru bahasa Indonesia kelas VII H di SMP N 4 Surakarta. Wawancara dilakukan pada tanggal 25 Oktober 2018 dalam waktu 19 menit 43 detik. Wawancara dilakukan untuk mengetahui pembelajaran, penerapan, kendala, dan upaya penyelesaian masalah dalam implementasi pembelajaran menulis cerita fantasi. Analisis dokumen dan observasi kelas digunakan sebagai pendukung data wawancara. Dokumen yang dianalisis yaitu berupa silabus dan RPP yang digunakan guru dalam proses belajar mengajar di kelas VII H. RPP yang dianalisis merupakan RPP yang digunakan guru dalam observasi kelas. Observasi kelas untuk memperoleh data penelitian ini dilakukan sebanyak 3 kali yaitu pada tanggal 18 September 2018, 19 September 2018, dan 8 Oktober 2018. Semua data penelitian hasil wawancara, observasi kelas dan analisis dokumen diuraikan berdasarkan fokus pertanyaan sebagai berikut.

\section{Perencanaan Pembelajaran Menulis Cerita Fantasi}

Mulyasa (2008: 255) menyatakan bahwa pembelajaran pada hakikatnya 
merupakan proses interaksi antara siswa dengan lingkungannya, sehingga terjadi perubahan tingkah laku ke arah yang lebih baik. Menurut Kurniawan (2014: 1) pembelajaran merupakan proses aktivitas yang dilakukan oleh guru dalam mengondisikan siswa untuk belajar. Kegiatan pembelajaran memuat rangkaian kegiatan yang harus dilakukan oleh peserta didik secara berurutan untuk mencapai kompetensi dasar. Penentuan urutan kegiatan pembelajaran harus sesuai dengan hierarki konsep materi pembelajaran (Priyatni, 2009:21). Dalam belajar siswa tidak hanya berinteraksi dengan guru sebagai salah satu sumber belajar, tetapi berinterakasi dengan keseluruhan sumber belajar yang mungkin dipakai untuk mencapai tujuan yang diinginkan (Rohmah, 2015:10).

Guru bahasa Indonesia kelas VII H SMP Negeri 4 Surakarta merencanakan pembelajaran menulis cerita fantasi dengan membuat RPP dan mengacu pada silabus. RPP yang digunakan oleh guru dalam pemebelajaran menulis cerita fantasi berdasar pada model RPP sebelumnya, yakni dengan model RPP kurikulum 2013. RPP teks cerita fantasi dirancang untuk 12 pertemuan. Adapun struktur dari RPP teks cerita fantasi meliputi identitas RPP, Kompetensi Inti (KI), Kompetensi Dasar (KD), indikator pencapaian kompetensi, tujuan pembelajaran, materi pembelajaran, metode pembelajaran, media dan alat pembelajaran, sumber belajar yang terdapat pada buku bahasa Indonesia pegangan siswa, seperti Kekuatan Ekor Biru Nagata, Ruang Dimensi Alpha, Berlian Tiga Warna, dan Belajar dengan Gajah Mada, Langkah-langkah Pembelajaran, dan Penilaian Hasil Belajar.

Materi pembelajaran pada dasarnya merupakan isi dari kurikulum, yakni berupa mata pelajaran atau bidang studi dengan topik atau sub topik dan rinciannya. Isi dari proses pembelajaran tercermin dalam materi pembelajaran yang dipelajari oleh siswa. Djamarah (2006:43) menerangkan materi pembelajaran adalah substansi yang akan disampaikan dalam proses belajar mengajar. Tanpa materi pembelajaran proses belajar mengajar tidak akan berjalan. Harjanto (2005:222) menjelaskan beberapa kriteria pemilihan materi pembelajaran yang akan dikembangkan dalam sistem pembelajaran dan yang mendasari penentuan strategi pembelajaran

Adapun langkah pembelajaran dibagi menjadi tiga, yaitu kegiatan pendahuluan, kegiatan inti, dan kegiatan penutup. Kegiatan pendahuluan berisi salam pembuka, menyanyikan lagu nasional, menyampaikan tujuan pembelajaran, serta penyampaian motivasi. Kegiatan inti memuat kegiatan $5 \mathrm{M}$ (mengamati, menanya, mengumpulkan data, mengasosiasi, dan menyimpulkan) dalam pembelajaran teks cerita fantasi. Kegiatan penutup berisi sebuah refleksi dari pembelajaran yang telah dilakukan pada jam pertemuan tersebut, penyampaian informasi, berdoa, dan salam penutup.

Berdasarkan Permendikbud nomor 22 tahun 2016, Rencana Pelaksanaan Pembelajaran (2016) adalah rencana kegiatan pembelajaran tatap muka untuk satu pertemuan atau lebih. RPP dikembangkan dari silabus untuk mengarahkan kegiatan pembelajaran peserta didik dalam upaya mencapai Kompetensi Dasar (KD). Guru merencanakan pembelajaran teks cerita fantasi dengan membuat RPP.

Setiap pendidik pada satuan pendidikan berkewajiban menyusun RPP secara lengkap dan sistematis agar pembelajaran berlangsung secara interaktif, inspiratif, menyenangkan, menantang, efisien, memotivasi peserta didik untuk berpartisipasi aktif, serta memberikan ruang yang cukup bagi prakarsa, kreativitas, dan kemandirian sesuai dengan bakat, minat, dan perkembangan fisik serta psikologis peserta didik. RPP disusun berdasarkan KD atau subtema yang dilaksanakan sekali pertemuan atau lebih 
Berikut adalah hasil obserasi dan analisis RPP yang digunakan guru dalam proses belajar mengajar di kelas VII H SMP N 4 Surakarta berdasarkan Permendikbud nomor 22 tahun 2016:

(1) RPP yang digunakan oleh guru untuk mengajar dikategorikan cukup baik, tetapi perlu diadakan perbaikan atau penambahan seperti metode pembelajaran. Pada RPP yang digunakan guru, metode pembelajaran yang digunakan belum tercantum. Akan tetapi dari hasil observasi yang dilakukan peneliti, guru lebih dominan menggunakan metode ceramah. Komponen-komponen lain dalam RPP sudah baik dan sesuai dengan Permendikbud nomor 22 tahun 2016

(2) Guru sudah menerapkan poin-poin yang terdapat dalam Kompetensi Inti yaitu mengajak siswanya untuk menerapkan KI-1 sampai KI-4, pada Kompetensi Dasar guru mengajak siswanya untuk menelaah struktur dan kebahasaan cerita fantasi yang dibaca dan didengar.

(3) Nilai-nilai karakter yang tercantum dalamm RPP disampaikan oleh guru kepada siswa dengan tujuan agar siswa dapat membangun dan memiliki nilai-nilai karakter tersebut.

(4) Tujuan pembelajaran disampaikan oleh guru dan telah sesuai dengan RPP yang digunakan. Guru menyampaikan tujuan belajar kepada siswa agar siswa mengetahui apa saja yang akan dilakukan agar tujuan pembelajaran dapat diterapkan secara maksimal.

(5) Kegiatan pembelajaran dalam RPP sudah diterapkan oleh guru secara maksimal. Pada kegiatan pembelajaran diawali dengan pendahuluan, kemudian terdapat kegiatan inti, dan diakhiri dengan kegiatan penutup.

(6) Penilaian yang digunakan guru terdiri dari teknik penilaian (penilaian sikap sosial, penilaian pengetauan, dan penilaian keterampilan) dan instrumen penilaian (instrumen jurnal dan instrumen pengetahuan).

(7) Pada kegiatan belajar mengajar guru menggunakan media pembelajaran yang cukup baik, karena telah sesuai dengan yang tercantum dalam RPP. Guru menggunakan media atau alat berupa LCD/ proyektor, dan contoh teks cerita fantasi. Guru juga menyediakan kertas dan dan bolpoin bagi siswa yang tidak membawa alat tulis. Hal ini sebagai antisipasi dari guru agar semua siswa dapat mengikuti pembelajaran dengan baik.

(8) Sumber belajar yang digunakan guru cukup lengkap, yaitu terdiri dari buku Bahasa Indonesia untuk kelas VII dari Kemendikbud, buku Tata Bahasa Baku Indonesia karya Hasan Alwi, dan Pedoman Umum Ejaan yang Disempurnakan.

\section{Pelaksanaan Pembelajaran Menulis Cerita Fantasi}

Menurut Purwadarminta (2006:144), Implementasi dapat diartikan sebagai suatu proses penerapan ide, konsep, kebijakan atau inovasi dalam suatu tindakan praktis sehingga memberi dampak, baik berupa pengetahuan, keterampilan maupun nilai dan sikap. Implementasi secara sederhana adalah pelaksanaan atau penerapan. Implementasi merupakan kegiatan untuk merealisasikan rencana menjadi tindakan nyata dalam rangka mencapai tujuan secara efektif dan efisien, sehingga akan memiliki nilai (Wiyani, 2012: 56). Usman (2002:70) menyatakan bahwa implementasi bermuara pada aktivitas, aksi, tindakan atau adanya mekanisme suatu sistem, implementasi bukan sekedar aktivitas, tapi suatu kegiatan yang terencana dan untuk mencapai tujuan kegiatan.

Pembelajaran pada hakikatnya adalah proses interaksi pada semua situasi yang ada di sekitar individu. Belajar dapat dipandang proses yang diarahkan melalui berbagai pengalaman. Belajar juga bisa 
diartikan sebagai akibat adanya interaksi antara stimulus dan respon (Nafisah, 2014:102). Pembelajaran adalah proses interaksi siswa dengan pendidik dan sumber belajar pada sebuah lingkungan belajar. Pembelajaran merupakan yang diberikan pendidik agar dapat terjadi proses perolehan ilmu dan pengetahuan. Dengan kata lain, pembelajaran adalah proses untuk membantu siswa agar dapat belajar dengan baik (Sanjaya, 2008:126).

Dalam suatu proses belajar mengajar, dua unsur uang amat penting adalah metode dan media pembelajaran. Kedua aspek ini saling berkaitan. Pemilihan salah satu metode pembelajaran tentu akan mempengaruhi jenis media pembelajaran yang sesuai, meskipun masih ada berbagai aspek lain yang harus diperhatikan dalam memilih media, antara lain tujuan pembelajaran, jenis tugas dan respon yang diharapkan siswa kuasai setelah pembelajaran berlangsung, dan konteks pembelajaran termasuk karakteristik siswa. Meskipun demikian, dapat dikatakan bahwa salah satu fungsi utama media pembelajaran adalah sebagai alat bantu mengajar yang turut mempengaruhi iklim, kondisi, dan lingkungan belajar yang ditata dan diciptakan oleh guru (Arsyad, 2010:15).

Maolani (2007:1) menyatakan bahwa metode secara harfiah berarti cara. Dalam pemakaian yang umum, metode diartikan sebagai cara melakukan sesuatu kegiatan atau cara melakukan pekerjaan dengan menggunakan fakta dan konsepkonsep secara sistematis.

Revell dan Arthur (2007) dalam artikel hasil penelitiannya yang berjudul "Character Education in Schools and the Education of Teachers" yang dimuat di Jurnal internasional menegaskan perlunya pendidikan nilai-nilai dalam pelatihan mengajar yang menerapkan pendidikan karakter. Perlu upaya untuk mempengaruhi dan mendorong peserta didik berperilaku dan bertindak tepat sesuai pendidikan karakter. Dalam pelaksanaan pembelajaran menulis cerita fantasi, guru juga harus menyisipkan pengetahuan kepada peserta didiknya mengenai pendidikan karakter.

Teks cerita fantasi merupakan salah satu teks baru yang terdapat dalam mata pelajaran Bahasa Indonesia kelas VII. Cerita fantasi merupakan cerita khayalan yang memiliki ciri khusus dan unik, sehingga dalam menggali ide atau gagasan untuk membuat cerita berdasarkan imajinasi masing-masing perlu adanya alat bantu berupa media pembelajaran dan pendekatan khusus yang dapat membantu peserta didik dalam menulis cerita fantasi (Lailia, 2018: 2). Menurut Harsiati (2017:44), cerita fantasi merupakan salah satu genre cerita yang sangat penting untuk melatih kreativitas dan cerita fantasi termasuk ke dalam teks narasi bersifat fiktif atau fiksi.

Pembelajaran teks cerita fantasi terdiri dari empat $\mathrm{KD}$, yaitu $\mathrm{KD} 3.3$ mengidentifikasi unsur-unsur teks narasi (cerita fantasi) yang dibaca dan didengar, KD 4.3 menceritakan kembali isi teks narasi (cerita fantasi) yang didengar dan dibaca, KD 3.4 menelaah struktur dan kebahasaan teks narasi (cerita fantasi) yang didengar dan dibaca, serta KD 4.4 menyajikan gagasan kreatif dalam bentuk cerita fantasi secara lisan dan tulis dengan memerlihatkan struktur dan penggunaan bahasa. Hal ini berdasarkan kurikulum 2013 revisi 2016. Pelaksanaan pembelajaran merupakan implementasi dari RPP, meliputi kegiatan pendahuluan, inti dan penutup.

Guru kelas VII H sudah menerapkan langkah-langkah pembelajaran dengan benar. Adapun pelaksanaan pembelajaran tersebut dibagi menjadi tiga, yaitu kegiatan pendahuluan, kegiatan inti, dan kegiatan penutup. Kegiatan pendahuluan berisi salam pembuka, menyanyikan lagu nasional, menyampaikan tujuan pembelajaran, serta penyampaian motivasi. Kegiatan inti memuat kegiatan $5 \mathrm{M}$ (mengamati, menanya, mengumpulkan data, mengasosiasi, dan menyimpulkan) dalam pembelajaran teks cerita fantasi. Kegiatan penutup berisi sebuah refleksi 
dari pembelajaran yang telah dilakukan pada jam pertemuan tersebut, penyampaian informasi, berdoa, dan salam penutup.

Guru memberikan materi tentang cerita fantasi pada pertemuan kesatu sampai keenam. Pada pertemuan ketujuh, guru hanya mengulas beberapa materi secara singkat kemudian dilanjutkan dengan ulangan harian. Arifin (2012: 24) mengungkapkan bahwa materi adalah isi kurikulum yang berupa topik atau pokok bahasan dan perincian dalam setiap mata pelajaran.

Setelah melakukan analisis RPP, materi yang diajarkan guru dari pertemuan kesatu sampai ketujuh di antaranya unsur pembangun cerita fantasi, jenis cerita fantasi, struktur cerita fantasi, menyimpulkan karakteristik bagianbagian struktur cerita fantasi, unsur kebahasaan cerita fantasi, dan cara menyajikan cerita fantasi.

Observasi pelaksanaan pembelajaran menulis cerita fantasi pada siswa kelas VII H SMP Negeri 4 Surakarta telah dilaksanakan sebanyak tiga kali. Pada observasi hari pertama guru mengajak siswa untuk melakukan tanya jawab tentang teks cerita fantasi. Hal ini dilakukan oleh guru guna mengukur seberapa penguasaan kompetensi yang sudah dipelajari sebelumnya.

\section{Kendala dalam Pembelajaran Menulis Cerita Fantasi}

Dalam setiap proses pembelajaran yang berlangsung, semuanya tidak dapat berjalan dengan mulus sesuai yang dikehendaki. Dalam pembelajaran pasti ditemukan beberapa kendala yang harus dihadapi baik oleh guru maupun oleh siswa. Menurut Hamalik (2001: 16-17) faktor penghambat dalam pembelajaran dapat berupa faktor manusiawi dan faktor institusional. Faktor manusiawi yaitu keterbatasan manusia, misalnya guru kurang mampu, siswa kurang mampu mengikuti pembelajaran, dan siswa berbeda satu sama lainnya. Faktor institusional seperti terbatasnya ruang kelas, laboratorium, alat peraga, dan sebagainya. Berdasarkan hasil observasi, pada dasarnya pembelajaran menulis cerita fantasi di kelas VII H SMP Negeri Surakarta sudah berjalan dengan baik. Akan tetapi tidak dapat dipungkiri bahwa dalam pembelajaran tersebut masih terdapat beberapa kendala. Kendala yang ditemukan pembelajaran menulis cerita fantasi adalah sebagai berikut. Kendala yang ditemui guru dalam proses pembelajaran menulis cerita fantasi meliputi (a) guru kurang bisa mengaktifkan dan mengondisikan siswa; (b) terbatasnya waktu dalam pembelajaran. Adapun kendala siswa adalah kurangnya penguasaan materi mengenai cerita fantasi hal ini terletak pada struktur teks cerita fantasi.

\section{Upaya Mengatasi Kendala}

Guru sebagai pendamping proses pembelajaran tentu saja harus mahir dalam mengidentifikasi masalah dan mencari solusi permasalahan (Chatib, 2011 dalam jurnal Sudiyati). Salah satu cara mengatasi masalah pembelajaran adalah dengan menggunakan media pembelajaran yang telah disesuaikan dengan masalah yang sedang terjadi dalam proses pembelajaran (kontekstual). Guru bisa mengetahui minat siswa melalui media yang mereka terapkan dan menciptakan suasana belajar yang menyenangkan dapat membuat siswa memahami dan menyerap materi yang disajikan dengan mudah (Hidayati dan Wuryandari, 2012:499).

Guru adalah pendidik yang menjadi tokoh, panutan, dan identifikasi bagi para peserta didik, dan lingkungannya. Guru sangat berperan dalam membantu perkembangan peserta didik untuk mewujudkan tujuan hidupnya secara optimal. Oleh karena itu guru harus mampu bertindak dan mengambil keputusan secara cepat, tepat waktu, dan tepat sasaran, terutama berkaitan dengan masalah pembelajaran dan peserta didik (Mulyasa, 2007:37). Guru tidak hanya seseorang yang bertugas mengajar, tetapi 
juga bertanggung jawab terhadap perkembangan karakter peserta didik. Guru bertanggung jawab untuk mewariskan sistem nilai kepada peserta didik dan menerjemahkan sistem nilai tersebut melalui kehidupan pribadinya (Barnawi dan M. Arifin, 2012:91).

Setelah melakukan serangkaian proses observasi maupun wawancara, tentunya ditemukan adanya kendalakendala dalam pembelajaran menulis cerita fantasi. Adapun yang kendala utama adalah guru belum melatih siswa untuk melalui tahapan menulis secara benar, yaitu ada tahap pramenulis, tahap menulis, dan tahap pascamenulis. Guru hanya memberitahu siswa harus menulis teks fantasi, tatpi tidak memberitahu langkahlangkahnya. Untuk mengatasi itu, upaya yang dilakukan untuk mengatasi kendala guru antara lain: (a) guru harus menerapkan metode yang inovatif dan meningkatkan rasa peduli terhadap siswa; (b) memanajemen waktu dengan sebaik mungkin. Metode yang dilakukan adalah dengan melatih siswa menulis melalui tahap yang lengkap, yaitu metode proses menulis. Itu sepertti yang disarankan Sumarwati (2019) dalam penelitiannya tentang pembelajaran menulis. Adapun upaya yang dilakukan untuk mengatasi kendala siswa ialah mengajak siswa untuk mencari berbagai macam teks cerita fantasi. Kemudian memberi tahu siswa mengenai batasan-batasan dari struktur teks cerita fantasi.

\section{SIMPULAN}

Berdasarkan hasil temuan penelitian dan pembahasan mengenai Implementasi Pembelajaram Menulis Cerita Siswa Kelas VII H SMP Negeri 4 Surakarta dapat disimpulkan sebagai berikut. Pertama, perencanaan pembelajaran menulis cerita fantasi siswa kelas VII H SMP Negeri 4 Surakarta sudah dirancang dengan baik. Dalam implementasi pembelajaran menulis cerita fantasi di SMP Negeri 4 Surakarta dilakukan melalui tahap perencanaan dan pelaksanaan. Kegiatan guru bahasa
Indonesia kelas VII H SMP Negeri 4 Surakarta di dalam perencanaan pembelajaran telah sesuai materi, metode, strategi, media, dan situasi pembelajaran. Hal ini diterapkan guru sesuai silabus dan RPP yang digunakan. RPP yang digunakan oleh guru dalam pemebelajaran menulis cerita fantasi berdasar pada model RPP sebelumnya, yakni dengan model RPP kurikulum 2013.

Kedua, pelaksanaan pembelajaran menulis cerita fantasi secara keseluruhan sudah berjalan dengan baik. Guru kelas VII H sudah menerapkan langkah-langkah pembelajaran dengan benar. Adapun pelaksanaan pembelajaran tersebut dibagi menjadi tiga, yaitu kegiatan pendahuluan, kegiatan inti, dan kegiatan penutup. Kegiatan pendahuluan berisi salam pembuka, menyanyikan lagu nasional, menyampaikan tujuan pembelajaran, serta penyampaian motivasi. Kegiatan inti memuat kegiatan 5 M (mengamati, menanya, mengumpulkan data, mengasosiasi, dan menyimpulkan) dalam pembelajaran teks cerita fantasi. Kegiatan penutup berisi sebuah refleksi dari pembelajaran yang telah dilakukan pada jam pertemuan tersebut, penyampaian informasi, berdoa, dan salam penutup.

Ketiga, kendala yang ditemui guru dalam proses pembelajaran menulis cerita fantasi meliputi (a) guru kurang bisa mengaktifkan dan mengondisikan siswa; (b) terbatasnya waktu dalam pembelajaran. Adapun kendala siswa adalah kurangnya penguasaan materi mengenai cerita fantasi hal ini terletak pada struktur teks cerita fantasi.

Keempat, upaya yang dilakukan untuk mengatasi kendala guru antara lain: (a) guru harus menerapkan metode yang inovatif dan meningkatkan rasa peduli terhadap siswa, yaotiu metode proses; (b) memanajemen waktu dengan sebaik mungkin. Adapun upaya yang dilakukan untuk mengatasi kendala siswa ialah mengajak siswa untuk mencari berbagai macam teks cerita fantasi. Kemudian 
memberi tahu siswa mengenai batasan-

\section{REFERENSI}

Arifin, Z. (2012). Penelitian PendidikanMetode dan Paradigma Baru. Bandung: Remaja Rosdakarya.

Arsyad, A. (1996). Media Pembelajaran. Jakarta: Raja Grafindo Persada.

Barnawi \& Arifin, M. (2012). Strategi dan Kebijakan Pendidikan Karakter. Yogyakarta: Ar-Ruzz Media.

Djamarah, S.B. (2000). Guru dan Anak Didik (Dalam Interaksi Edukatif). Jakarta: Rineka Cipta.

Hamalik, O. (2001). Perencanaan Pembelajaran Berdasarkan Pendekatan Sistem. Jakarta: PT. Bumi Aksara.

Harjanto. (2005). Perencanaan Pembelajaran. Jakarta: Bumi Aksara.

Harsiati. (2017). Bahasa Indonesia SMP/MTs edisi revisi. Jakarta: Kementrian Pendidikan dan Kebudayaan.

Hidayati, N. \& Wuryandari. (2012). Media Design for Learning Indonesian in Junior High School Level. Procedia Journal: Social and Behaviora Sciences. 67, 490-499. Diperoleh 3 Januari 2019 dari https://www.sciencedirect.com/scien ce/article/pii/S1877042812053402.

Kurniawan, H. (2014). Pembelajaran Menulis Kreatif. Bandung: PT Remaja Rosdakarya.

Laila, I. (2018). Pengembangan Media Buku Permainan Labirin Fantasi (Buperlafa) dalam Pembelajaran Menulis Cerita Fantasi Berbasis Psychowriting Kelas VII SMP Negeri 1 Cerme, Gresik. Jurnal Pendidikan Bahasa dan Sastra Indonesia 1 (1) 1-10.

Maolani, I. (2007). Metode Pembelajaran. Jakarta: Nusa Indah.

Moleong, L.J. (2010). Metodologi Penelitian Kualitatif. Bandung: Remaja Rosdakarya Offset. batasan dari struktur teks cerita fantasi.

Mulyasa, E. (2007). Menjadi Guru Profesional: Menciptakan Pembelajaran Kreatif dan Menyenangkan. Bandung: PT Remaja Rosdakarya.

__. (2008). Kurikulum Tingkat Satuan Pendidikan: Sebuah Panduan Praktis. Bandung: PT Remaja Rosdakarya.

Nafisah. Y. (2014). Implementasi Kurikulum 2013 pada Mata Pelajaran Pendidikan Agama Islam dan Budi Pekerti di Sekolah Menengah Atas Negeri 2 Wates. Skripsi. UIN Sunan Kalijaga.

Peraturan Menteri Pendidikan dan Kebudayaan No. 22 Tahun 2016 tentang Standar Proses Pendidikan Dasar dan Menengah.

Revell, L \& Arthur., J. (2007). Character Education in Schools and the Education of Teachers. Journal of Moral Education. 36(1), 79-92.

Priyatni, E.T. (2009). Buku Petunjuk Teknis Praktik Pengalaman Lapangan Bidang Studi Pendidikan Bahasa dan Sastra Indonesia. Malang: Universitas Negeri Malang.

Purwadarminta, W.J.S. (2006). Kamus Bahasa Umum Indonesia. Jakarta: Balai Pustaka.

Rohmah, F. (2015). Implementasi Pembelajaran Membaca Al-Quran Metode UMMI di MI Sambas Purbalingga Tahun Pelajaran 2014/2015. Skripsi. Universitas Muhamadiyah Purwokerto.

Sanjaya, W. (2008). Strategi Pembelajaran Berorientasi Standar Proses Pendidikan. Jakarta: Kencana.

Sudiyati. (2017). Keefektifan Pembelajaran Berbasis Pendidikan Kewirausahaan Berbantuan Buku Panduan Motivatif dalam Meningkatkan Kemampuan Menulis Cerita Pendek. Jurnal Pendidikan 
Bahasa Indonesia. 5(1), 68-75. http://jurnal.unissula.ac.id/index.php /jpbsi/article/view/2094/1595.

Sumarwati. (2019). Peningkatan Kualitas

Pembelajaran Menulis melalui Pendekatan Proses pada Siswa di Kelas V Sekolah Dasar, Jurnal Logat, 6(2), 151-167.

Tarigan, H.G. (2013). Menulis Sebagai Suatu Ketrampilan Berbahasa. Bandung: Angkasa.

Usman, N. (2002). Konteks Implementasi Berbasis Kurikulum. Jakarta: Lembaga Informasi Nasional.

Wiyani, N.A. (2012). Manajemen Pendidikan Karakter; Konsep dan Implementasi di Sekolah. Yogyakarta: PT Pustaka Insan Madani. 